\title{
Equisetalean Plant Remains from the Early to Middle Triassic of New South Wales, Australia
}

\author{
W.B. KeITH HolmeS \\ "Noonee Nyrang", Gulgong Road, Wellington NSW 2820, Australia \\ Honorary Research Fellow, Geology Department, University of New England, Armidale NSW 2351, Australia \\ wbkholmes@hotmail.com \\ Present address: National Botanical Institute, Private Bag X101, Pretoria, 0001, South Africa
}

\begin{abstract}
Equisetalean fossil plant remains of Early to Middle Triassic age from New South Wales are described. Robust and persistent nodal diaphragms composed of three zones; a broad central pith disc, a vascular cylinder and a cortical region surrounded by a sheath of conjoined leaf bases, are placed in Nododendron benolongensis $\mathrm{n}$.sp. The new genus Townroviamites is erected for stems previously assigned to Phyllotheca brookvalensis which bear whorls of leaves forming a narrow basal sheath and the number of leaves matches the number of vascular bundles. Finely striated stems bearing leaf whorls consisting of several foliar lobes each formed from four to seven linear conjoined leaves are described as Paraschizoneura jonesii $\mathrm{n}$.sp. Doubts are raised about the presence of the common Permian Gondwanan sphenophyte species Phyllotheca australis and the Northern Hemisphere genus Neocalamites in Middle Triassic floras of Gondwana.
\end{abstract}

Holmes, W.B. Keith, 2001. Equisetalean plant remains from the Early to Middle Triassic of New South Wales, Australia. Records of the Australian Museum 53(1): 9-20.

The plant Phylum Sphenophyta, which includes the equisetaleans, commonly known as "horse-tails" or "scouring rushes", first appeared during the Devonian Period (Taylor \& Taylor, 1993). By the Carboniferous Period the Sphenophyta had reached their greatest degree of diversity, when, as semi-aquatic or swamp-dwelling scramblers, small herbaceous plants or even trees to $20 \mathrm{~m}$ in height, they formed a prominent part of the vegetation of the coal swamps of northern Pangaea, or, what is today, Europe and North America (Boureau, 1964). During the
Permian Period, the increasing aridity and decline in the vegetation of northern Pangaea was in contrast to that in southern Pangaea-Gondwana-where flourishing swamp forests of the Glossopteris Flora were producing some of the world's greatest coal reserves. A limited range of sphenophytes (Townrow, 1955; Rigby, 1966; McLoughlin, 1992a,b; Holmes, 1995) including Phyllotheca australis, a significant contributor to the formation of the coal (Beeston, 1991; McLoughlin, 1993) and fodder for dicynodont mammallike reptiles (Rayner, 1992), were associated with Glossopteris. 
The catastrophic end-Permian extinction event brought about the demise of the Glossopteris Flora (Retallack, 1995; McLoughlin et al., 1997). A new, low diversity flora appeared in the Early Triassic sediments overlying the topmost Permian coal seams in the Sydney Basin. This flora included the pteridosperm "Thinnfeldia" callipteroides, some ferns, conifers and lycopods, the sphenophyte Schizoneura gondwanensis and other associated equisetalean remains (Retallack, 1980). By the late Middle Triassic, the vegetation of Gondwana had diversified to a degree that was not surpassed until the rise to dominance of the angiosperms in the Cenozoic (Anderson et al., 1999). During the Middle and Late Triassic, equisetalean sphenophytes had a cosmopolitan distribution and often formed monoculture thickets in waterlogged environments. However, they failed to regain the diversity reached during the Carboniferous Period.

From the Early and Middle Triassic of New South Wales, fossil equisetaleans of varying degrees of preservation are known from the Sydney Basin (Walkom, 1925; Townrow, 1955; Retallack, 1973, 1980), the Lorne Basin (Holmes \& Ash, 1979), the Great Artesian Basin (Holmes, 1982) and the Nymboida Coal Measures (Retallack, 1977; Holmes, 2000; see Fig. 1). Subsequent to the Triassic, the sphenophytes went into a decline and today they are represented by a single genus, Equisetum with about 20 extant species (Hauke, 1983; Taylor \& Taylor, 1993) none of which occur in Australia.

With the exception of a silicified stem Spaciinodum collinsonii Osborn \& Taylor, 1989, from Antarctica and a nodal diaphragm Nododendron suberosum Artabe \& Zamuner, 1991, from Argentina, Gondwana Triassic equisetaleans are poorly documented and illustrated. In some cases, leaf-bearing stems have been referred, on doubtful grounds, to species described from the Northern Hemisphere or from different geological periods.

The Palaeontology Collection of the Australian Museum includes some noteworthy Triassic equisetalean material that is here described and illustrated.

\section{Systematic palaeobotany}

\section{Phylum Sphenophyta}

\section{Order Equisetales incertae sedis}

Genus Nododendron Artabe \& Zamuner, 1991

Type species. Nododendron suberosum Artabe \& Zamuner, 1991 - nodal diaphragm only, Potrerillos Formation, Cacheuta Basin, Argentina. Early Late Triassic.

Emended diagnosis. Equisetalean nodal diaphragms differentiated into three zones; a central medullary disc of robust persistent tissue encircled by a vascular cylinder composed of a ring of vascular bundles two or more times more numerous than number of leaves in surrounding whorl; and a cortex composed of inner ring of periderm and outer ring of secondary growth in the cortex and/or sheath of conjoined and persistent leaf bases.

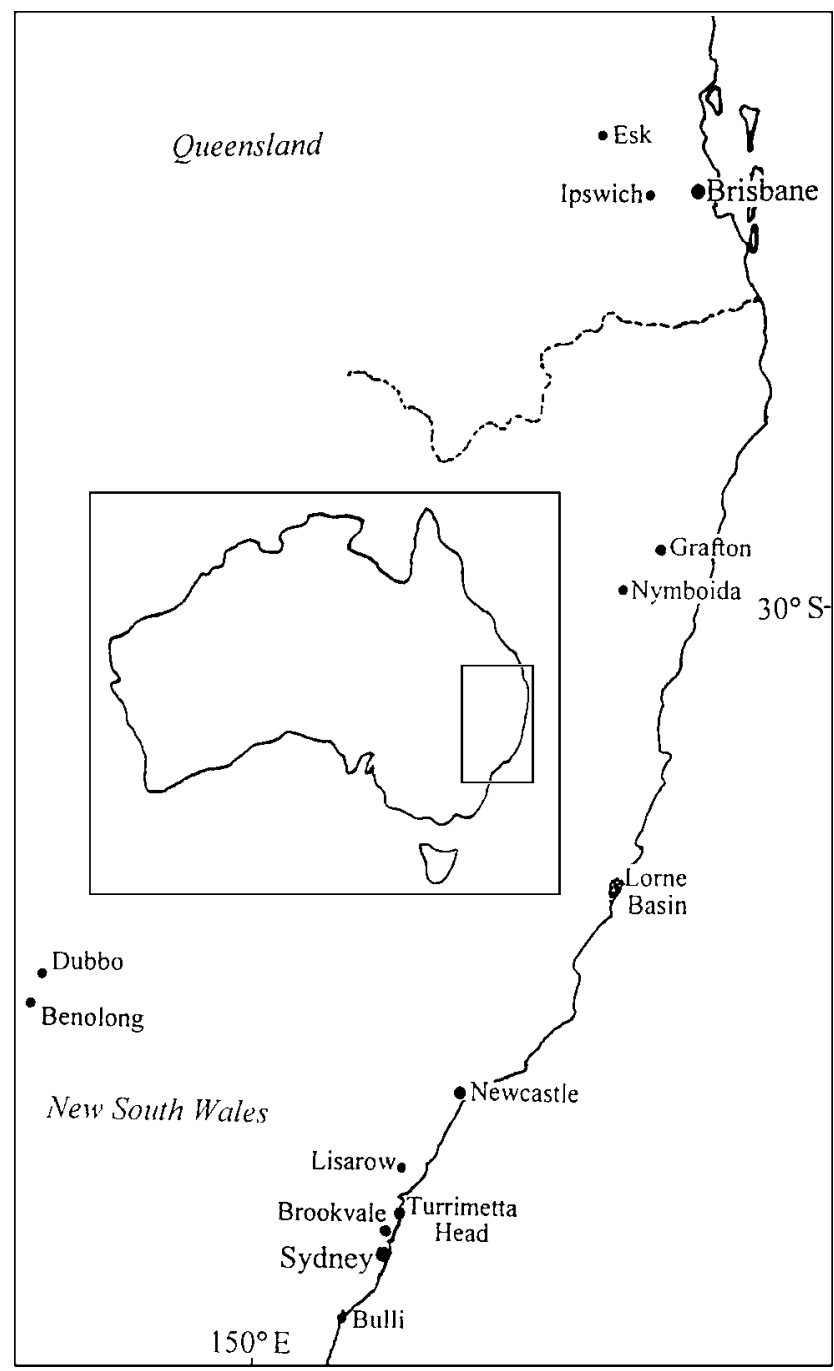

Figure 1. Eastern Australian fossil equisetalean localities mentioned in text.

\section{Nododendron benolongensis n.sp.}

Figs. 2A-C, 3A-C

Diagnosis. A diaphragm with ring of closely spaced vascular bundles; cortical zone undulate with fluted margins, surrounded by persistent sheath of conjoined leaf bases. Vascular bundles twice number of leaves.

Description. Eight almost complete nodal diaphragms together with fragments of equisetalean stems and ginkgoalean leaves are preserved as impressions on the surface of the partially baked claystone slab AM F51397 (Fig. 2A).

The nodal diaphragm selected as the holotype, (Fig. 2B) is preserved as a slightly distorted disc with an external diameter of 18 to $23 \mathrm{~mm}$. The medullary disc has a smooth surface and a diameter of 9 to $12 \mathrm{~mm}$. Surrounding the pith disc is a vascular cylinder with a ring of c. 48 bundles, each circular to triangular in cross section. A cortical zone, c. 3 $\mathrm{mm}$ in width, surrounds the vascular cylinder. The outer portion of the cortex is undulate or fluted and surrounded 


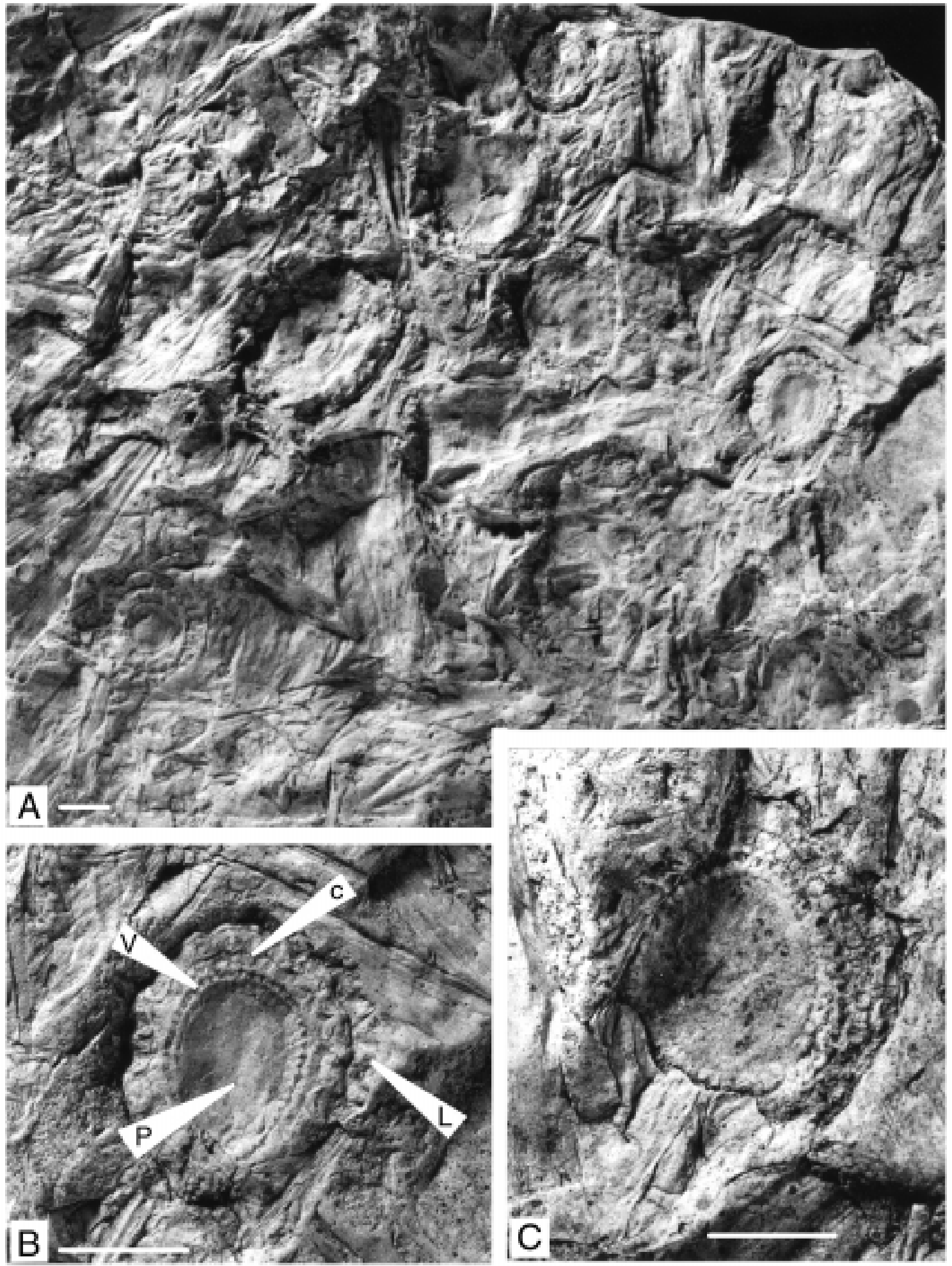

Figure 2. A-C, Nododendron benolongensis n.sp. from Benolong. A, AM F51397, portion of a large slab with eight nodal diaphragms, fragments of sphenophyte leaves and stems and portions of Sphenobaiera ugotheriensis leaves. B, holotype, AM F113364; P, pith or medullary zone; V, vascular cylinder with ring of vascular bundles; c, cortical zone; L, leaf lamina contracting from basal sheath. C, paratype, AM F113374. Scale bars $1 \mathrm{~cm}$. 


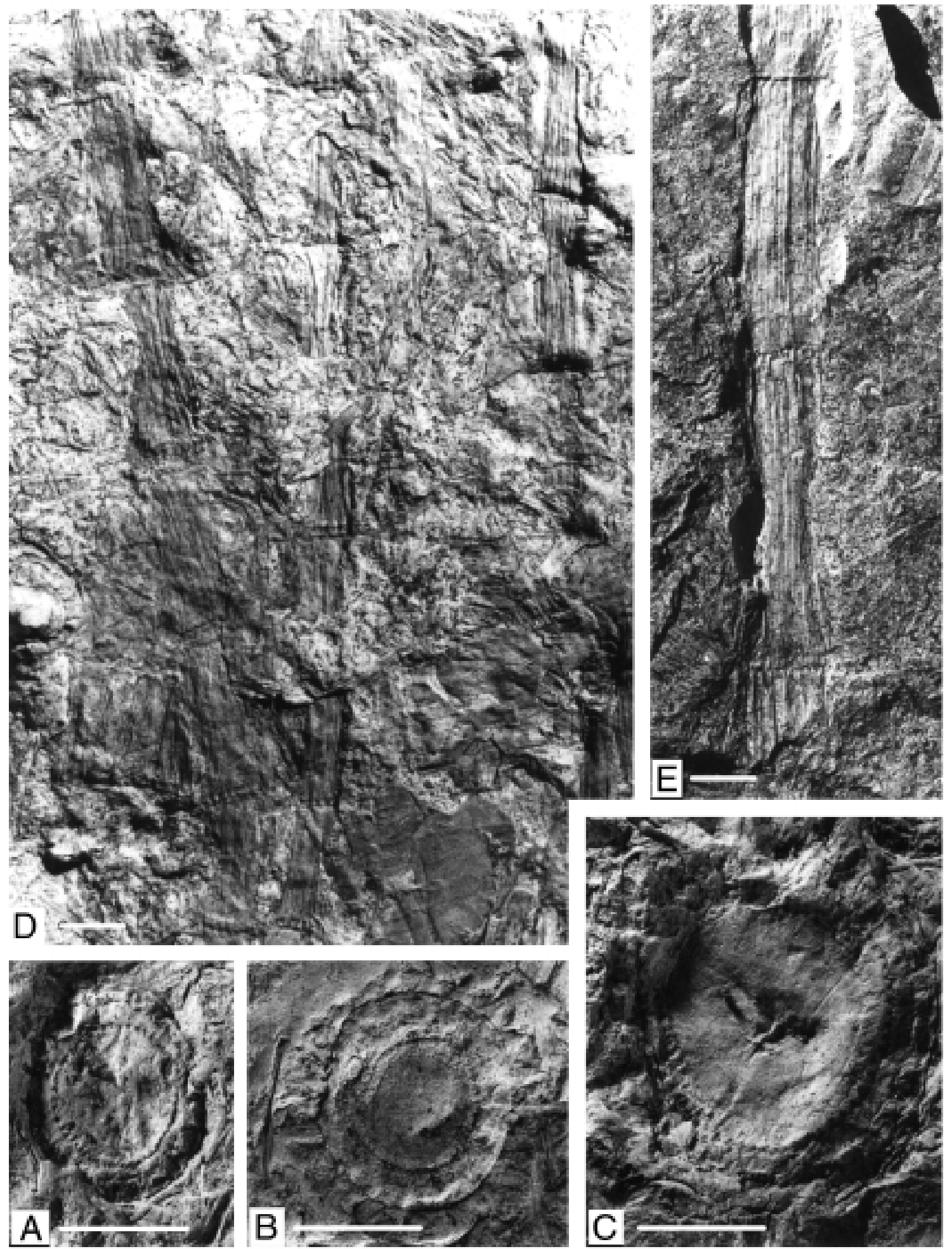

Figure 3. A-C, paratypes, Nododendron benolongensis n.sp. from Benolong. A, AM F113373; B, AM F113363; C, AM F113365. D,E, equisetalean stems associated with Nododendron benolongensis from Benolong; D, AM F61114; E, AM F61113. Scale bars $1 \mathrm{~cm}$. 
by a sheath of conjoined leaf bases. The leaves contract and separate distally into linear laminae c. 1 to $1.5 \mathrm{~mm}$ wide. All the leaves are broken off close to the base so that their length is not known. Other nodal diaphragms on the slab are circular, from 18 to $30 \mathrm{~mm}$ in diameter and with rings of from 35 to 60 vascular bundles. There are half as many leaves as vascular bundles. Cell structure is not preserved on any of the diaphragms.

Type material. HOLOTYPE: AM F113364 Australian Museum, Sydney, New South Wales. PARATYPES: AM F113362, F113363, F113365 and F113366. All on slab AM F51397.

Type locality. "Ugothery", Portion 31, Parish of Benolong, Dubbo, N.S.W. Napperby Formation, Great Artesian Basin, late Early to early Middle Triassic (see Holmes, 1982; Cameron et al., 1999). Grid reference, 6546006408900 , Dubbo Geological Series Sheet, 1:250 000, 1999, $32^{\circ} 26^{\prime} 46^{\prime \prime S} 148^{\circ} 38^{\prime} 40^{\prime \prime E}$.

Etymology: benolongensis-from the Benolong district, near Dubbo, New South Wales.

Discussion. Nododendron suberosum Artabe \& Zamuner, the type species for the genus, is based on a single specimen (Number 2076B) and its counterpart (20167) which I have examined in the Palaeobotanical Collection of the Museo de La Plata, La Plata, Argentina. The specimen comprises a nodal diaphragm in transverse section and a dissociated portion of a longitudinal section of an equisetalean stem showing four nodes and three internodes all preserved as impressions with some limonite replacement of the original organic material. The surface of the specimen appears to have been treated with a surface hardener and the matrix between the node and the stem has been polished. Frenguelli (1949) first described the specimen and placed it in Neocalamites carrerei (Zeiller) Halle, originally erected for equisetalean foliage-bearing stems from the Upper Triassic of China (Zeiller, 1903). Based on an anatomical and morphological study, Artabe \& Zamuner (1991) reassigned Frenguelli's specimen to Nododendron suberosum, including both the diaphragm and stem under the same name. Using a binocular microscope and low angle lighting I was unable to confirm the cell structure on the surface of the diaphragm as described by Artabe \& Zamuner. The outer portion of the diaphragm illustrated on plate 2.2 of Artabe \& Zamuner (1991) was described as a "branch with a whorl of Asterophyllites-type leaves". My examination of this "whorl" showed it to be a fragment of a broad leaf with a number of irregular and discontinuous veins, preserved on the surface of a thin layer of sediment overlying and quite separate from the layer on which the Nododendron node is preserved. There was no evidence of nodes or whorls of leaves on any of the other "branches", which I interpret as leaves.

The erection of Nododendron as a form genus for robust and detached equisetalean diaphragms is a useful means of classifying these plant organs that are commonly found dispersed and separate from the parent plant. I have emended the generic diagnosis to include nodal diaphragms only and, recognizing that the vast majority of fossil material will not have cell structure preserved, the diagnosis is based only on gross morphological features.

Nododendron benolongensis differs from $N$. suberosum by the presence of a conspicuous ring of vascular bundles in the vascular cylinder; by the undulate and fluted appearance of the cortical zone; by the lack of visible vascular traces traversing the cortex and by its much smaller size. Nododendron suberosum appears to have about four times the more vascular bundles than leaves, compared with two bundles per leaf in $N$. benolongensis.

The single diaphragm assigned to ?Nododendron sp. from early Middle Triassic Nymboida Coal Measures of northern New South Wales (Holmes, 2000) is not sufficiently well preserved for specific identification.

A nodal diaphragm from the Ipswich Coal Measures of Queensland, illustrated by Hill et al. (1965, pl. T1, fig. 2) as Neocalamites cf. carrerei differs from $N$. benolongensis by the obscure vascular zone and by the wide cortical zone of rectangular or slightly wedge-shaped segments with a plicated appearance.

Other Gondwanan Triassic nodal diaphragms that differ in form from Nododendron and are closer to extant Equisetum, have been referred to Equisetites by Walkom (1915), Du Toit (1927) and Artabe (1985). Walkom (1925) assigned a node from the Narrabeen Series to Phyllotheca australis. Gould (1968) noted that solid diaphragms are characteristic of Equisetum rather than Phyllotheca. Persistent nodal diaphragms are notably absent from Permian Phyllotheca australis assemblages (Townrow, 1955: 59) and I suspect that Phyllotheca australis together with Glossopteris did not survive the end-Permian extinction event.

A nodal diaphragm from Argentina assigned to Equisetites fertilis (Artabe, 1985, pl. 1, fig. 2) appears to be divided into three zones as in Nododendron, but the preservation does not allow for a close comparison. In a revision of Kurtz (1921), Archangelsky et al. (1995) suggested that $E$. fertilis was an immature stage of Neocalamites carrerei. However, the presence of the persistent nodal diaphragms raises doubts that this plant is N. carrerei sensu Halle (1908).

Many Gondwanan equisetalean leaf-bearing stems have been placed in the genus Neocalamites (Halle, 1908), the diagnostic feature being that the leaves are free to the base. Complex and persistent nodal diaphragms have not been recorded in association with Neocalamites from the Northern Hemisphere. On both the Argentinian and Australian Nododendron nodes, the attached whorls of foliage, although very incomplete, show the leaves expanding and conjoining basally to form a continuous sheath around the node. I have examined the specimens of foliage-bearing stems from eastern Australia that were described as having leaves free to the base and were placed subsequently in either Neocalamites hoerensis or N. carrerei by Walkom (1915, pl. 2, fig. 1); Jones \& de Jersey (1947, text-fig. 2); Hill et al. (1965, pl. T1, figs. 1,2) and Playford et al. (1982, pl. 2, fig. 7). In all cases, the material is not preserved well enough to determine the method of attachment of the leaf whorls to the node or whether the leaves were indeed free to the base. The presence of nodal 
diaphragms and leaves conjoining to form a short basal sheath, as in Nododendron species from New South Wales and Argentina, suggests that some at least of Gondwana equisetaleans are generically distinct from the contemporaneous equisetalean plants from the Northern Hemisphere.

\section{Equisetalean stems associated with Nododendron benolongensis}

Figs. 3D,E

Closely associated with the nodal diaphragms described above, are numerous impressions of external moulds of equisetalean stems and fragments of detached linear leaves (Fig. 3D). None of the stems are preserved in a manner to show the attachment of the leaves. The external surface of the internodes is smooth, or coarsely and irregularly grooved, with the number of broad ribs approximating the number of leaf scars on the nodes. The nodes are slightly expanded and sometimes marked by a distinct transverse groove below the line of scars. Stems preserved as internal pith casts (Fig. 3E) show fine longitudinal striations representing the vascular bundles which are twice the number of the scars visible on the nodes. The width of the stems varies from 5 to $30 \mathrm{~mm}$. The internodal length is roughly related to the width of the stem and position on the plant. Internodes are c. $50 \mathrm{~mm}$ long near the stem base but gradually decrease in length distally. On the nodes of compressed stems $12 \mathrm{~mm}$ wide, there are ten leaf scars visible, which indicates a complete whorl of 20 leaves. The ratio of vascular bundles to number of leaves is similar to that of N. benolongensis and Neocalamites (Halle, 1908) but differs from Townroviamites n.gen. described below, which has the same number of leaves as vascular bundles.

Zalessky (1932) erected the form genus Paracalamites to include leafless stems on which the ribs and grooves passed through the nodes without alternation. A number of species have been erected for stems from the Permian of Siberia (Boureau, 1964) and from Australia (Rigby, 1966). As Paracalamites, by definition, is based on only a few characters, such as density of the ribs and ratio of stem width to internode length, which vary considerably between stems in the same assemblage, I believe that erecting a new species of Paracalamites for the Benolong stems would be of little value.

Although the stems illustrated in Fig. 3D,E have a smaller diameter than the nodal diaphragms illustrated in Figs. 2AC, 3A-C, their close taphonomic association with $N$. benolongensis suggests they are probable biological associates.

\section{Genus Townroviamites n.gen.}

Type species. Townroviamites brookvalensis (Townrow, 1955: 53) n.comb. (from Phyllotheca)

Generic diagnosis. Sphenophyte with longitudinal ribs passing without alternation through node. Nodal region complex, with a transverse groove bounded above and below by transverse ridges. Linear leaves conjoined close to base to form narrow collar at node. Number of leaves in whorl the same as the number of vascular bundles in the internodal vascular cylinder.

Etymology. Townrovia-for Dr J.A. Townrow, eminent palaeobotanist who made significant contributions to the knowledge of Australian Triassic floras and who was the first to recognize this plant as a new taxon; mites suggests affinities with other equisetalean plants.

\section{Townroviamites brookvalensis (Townrow, 1955: 53) n.comb.}

$$
\text { Figs. 4A-C, 5A-C }
$$

1955 Phyllotheca brookvalensis Townrow, p. 53, text-figs. 4AC, 5A,B.

The diagnosis for Phyllotheca brookvalensis (Townrow, 1955: 53-54) was a lengthy and detailed description of the type material in the British Museum. That diagnosis is here emended to include the range of variation within all populations referable to this species.

Emended diagnosis. Stems with broad longitudinal ribs; nodes somewhat expanded, showing a transverse depression bounded by narrow transverse ridges. Leaves equal in number to vascular bundles. Leaves coalescing to form a short basal collar; linear, thick texture; median vein sometimes present; number of leaves in each whorl approximately equal to circumference of stem in millimetres.

Description. The type material of Townrow (1955) was based on a part of the Tillyard Collection from the Beacon Hill Quarry in the northern Sydney suburb of Brookvale and is housed in the Geology Department of the Natural History Museum, London. Additional material in the Australian Museum from the type locality and from a new locality at Lisarow near Gosford, extends our knowledge of the range of variation within this taxon.

From the Brookvale locality, one specimen (Fig. 4A) has two whorls of about 16 leaves to $65 \mathrm{~mm}$ long and to 1.5 mm wide. Another (Fig. 4C) has a single smaller whorl of c. 10 leaves, each to c. $20 \mathrm{~mm}$ long and to $1 \mathrm{~mm}$ wide.

The specimens from a now abandoned roadfill quarry in a white siltstone lens in the Terrigal Formation at Lisarow, near Gosford, consist of internal casts and external moulds of stems, a nodal diaphragm and whorls of leaves. An almost complete detached whorl of 30 leaves (Fig. 5A) borne around a stem $10 \mathrm{~mm}$ in diameter shows the leaves conjoining basally and decurving through $180^{\circ}$ to form a vertical collar into the matrix. The leaves of the type material were stated by Townrow (1955) as having a "midrib clearly marked over most of the leaf". In this additional material, the leaf midvein is rarely evident and the leaf lamina is often marked by several faint longitudinal striations, but this may be a feature of preservation due to wrinkling of the leaves along aligned epidermal cells. The nodal diaphragm (Fig. 5C), associated with $22 \mathrm{~mm}$ wide internal casts of finely striated stems (Fig. 5D), is preserved as a faint iron-stained impression with a vascular ring containing 

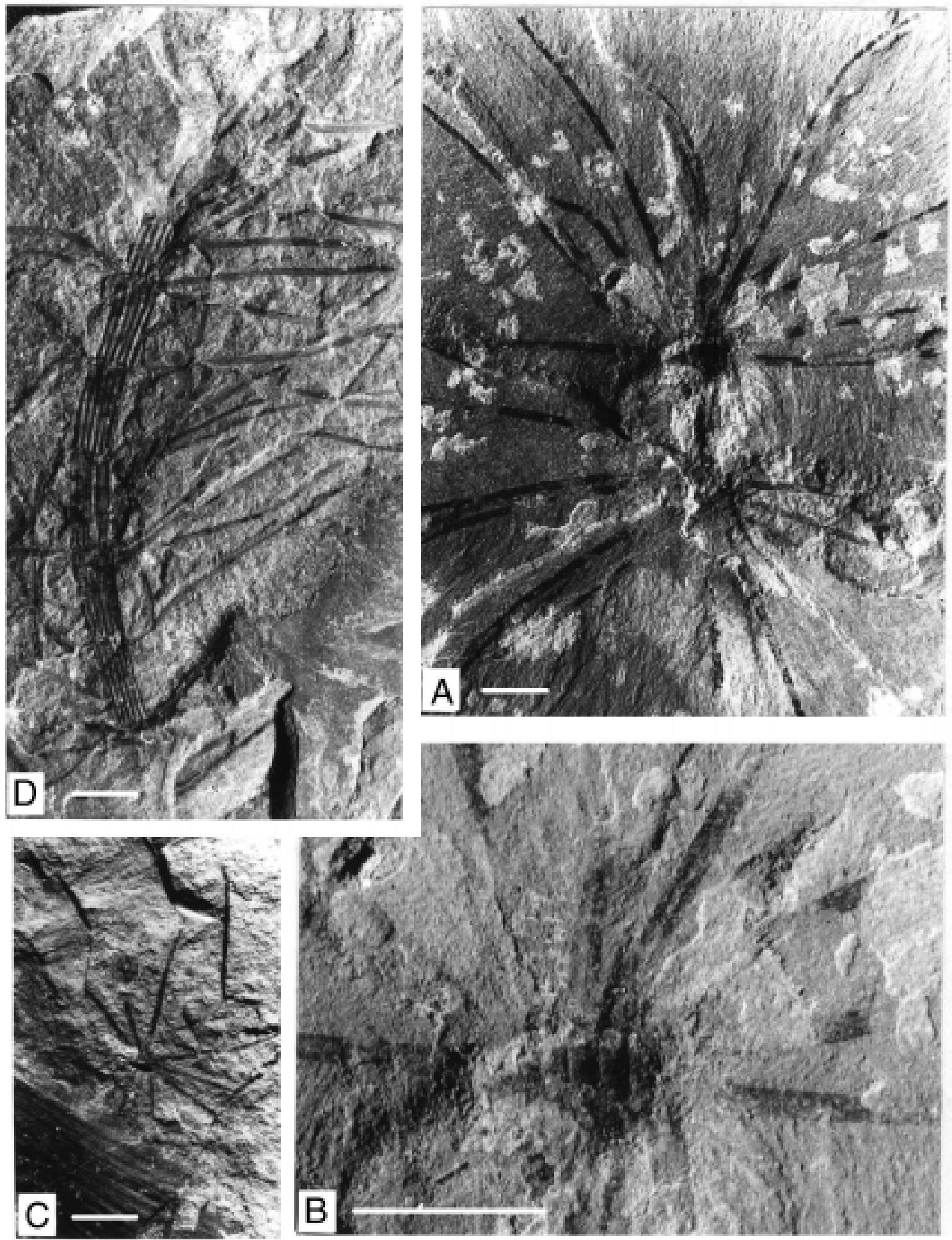

Figure 4. A-C, Townroviamites brookvalensis n.comb. from Beacon Hill Quarry, Brookvale; A, AM F18616, two leaf whorls; B, AM F18616, portion of leaf whorl and node; C, AM F18617, small leaf whorl. D, AM F38273, equisetalean stem with apparently attached leaves associated with $T$. brookvalensis. Scale bars $1 \mathrm{~cm}$.

c. 90 bundles in a stem with an external circumference of c. $94 \mathrm{~mm}$. Preserved on the same horizon is an external mould of a stem (Fig. 5E) c. $10 \mathrm{~mm}$ wide and with internodes c. $30 \mathrm{~mm}$ long. Poorly defined external longitudinal ribs appear to pass without alternation across the nodes. There is a transverse line of small circular leaf scars at each node, but the diagnostic transverse groove and ridges at the nodes are not evident.

Based on all available specimens of $T$. brookvalensis, the ratio of the number of leaves to stem circumference in 

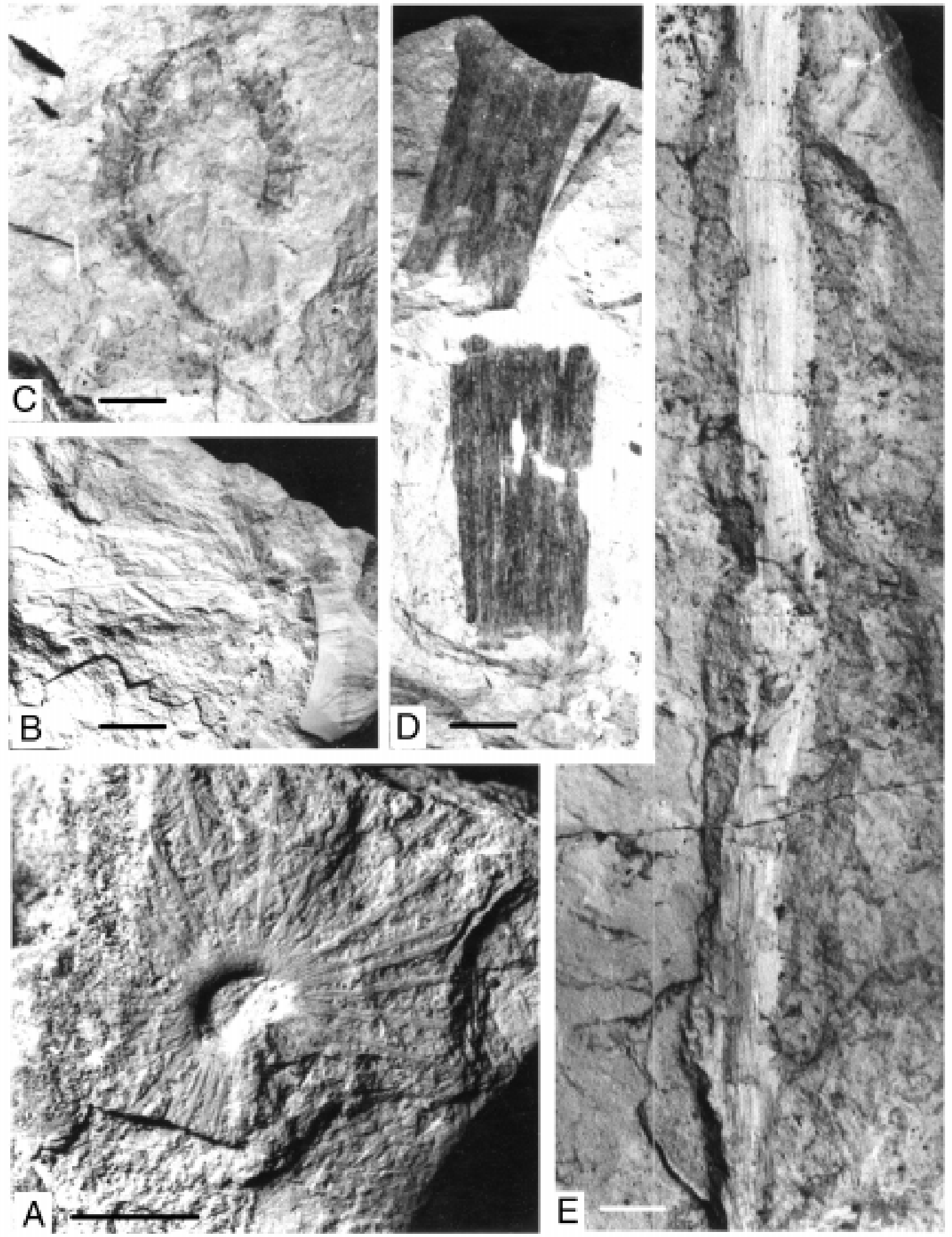

Figure 5. A-E, Townroviamites brookvalensis n.comb. from Lisarow Quarry; A,B, leaf whorls; A, AM F113356; B, AM F113358; C, nodal diaphragm with ring of vascular bundles, AM F113354; D, internal cast of large stem, AM F113354; E, external mould of stem with c. 10 leaf scars across nodes, AM F113359. Scale bars $1 \mathrm{~cm}$. 
$\mathrm{mm}$ ranges from 1:0.5 to 1:1.3 with an average of 1:1. This compares with a ratio of 1:4.5 and 1:2 for Nododendron suberosum and $N$. benolongensis respectively.

Type material. LECTOTYPE: V31862a, Natural History Museum, London. PARATYPES: V31857, V31859, V31860 (NHM).

Type locality. Beacon Hill Quarry, Brookvale, near Sydney. Brookvale Shale Lens of the Hawkesbury Sandstone, Sydney Basin, early Middle Triassic (Retallack, 1977, microfiche frame G10). GR 387 638, 1:100 000, Sydney

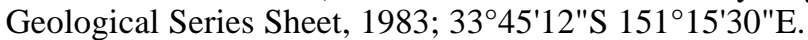

Additional material. AM F18616, F18617 from Brookvale and AM F113352-61 from the Lisarow Quarry, Terrigal Formation, Sydney Basin; late Early to early Middle Triassic.

Discussion. In his original description of Phyllotheca brookvalensis, Townrow (1955) expressed doubt as to the correct generic position of this equisetalean plant fossil, but he considered it nearest to Phyllotheca and Neocalamites. Townroviamites differs from Phyllotheca, which is essentially a Permian genus (see above), by its reduced leaf sheath and by its complex nodal region. It differs from Neocalamites by its basally conjoined leaves which form a short sheath and having the same number of leaves as vascular bundles. Plants with Nododendrontype diaphragms have a greater number of vascular bundles than leaves.

The Lisarow locality is stratigraphically below that of the Beacon Hill Quarry. While the available Lisarow material conforms with the diagnosis for T. brookvalensis, additional material may show it to be specifically distinct.

The leafy stem (Fig. 4D) from the Beacon Hill Quarry, is preserved in a similar matrix to the leaf whorls in Fig. 4A-C. White (1986) referred this specimen to Neocalamites hoerensis. However, any identification is uncertain because the form of the leaf bases and their attachment to the stem cannot be determined. Also, the nodes lack the diagnostic groove and ridges of Townroviamites.

Northern Hemisphere Neocalamites carrerei and $N$. hoerensis have been differentiated partly on the density and width of the leaves in a leaf whorl (Boureau, 1964). It is probable that Gondwana Triassic leaf-bearing stems that were assigned previously to $N$. carrerei and $N$. hoerensis should now be re-assessed for inclusion in either Townroviamites or as a Nododendron-bearing plant.

Due to the absence of a diagnostic feature such as the ratio of the number of leaves to the number of vascular bundles, the classification of many Gondwanan Triassic leaf whorls will remain unresolved. Among such indeterminate leaf whorls are examples of linear leaves conjoining to form a short basal sheath, described by Du Toit (1927, pl. 6, fig. 6) from South Africa as Neocalamites carrerei; by de Cabrera (1971, fig. 6) from Argentina as Neocalamites sp. and by Anderson \& Anderson (1985, pl. 190, fig. 1) as Phyllotheca sp.

\section{Genus Paraschizoneura Radczenko, 1955 (in Boureau, 1964)}

Type species. Paraschizoneura siberica (Neuberg, 1948), (Radczenko, 1955 in Boureau, 1964).

\section{Paraschizoneura jonesii n.sp.}

Figs. $6 \mathrm{~A}-\mathrm{C}$

1915 Schizoneura(?) cf. africana Feistmantel. Walkom, p. 35, pl. 3, fig. 1.

1924 Schizoneura sp. "a" Seward. Walkom, pp. 79-80, textfig. 1.

?1965 Schizoneura sp. "a" Seward. Hill et al., pl. T1, fig. 4.

?1973 Schizoneura sp. Retallack, pl. 5, figs. 4, 8.

Diagnosis. Sphenophyte foliage bearing stems with whorls of four or more elongate foliar segments each consisting of five or more linear leaves conjoined for their whole length and arranged radially around axial nodes.

Description. The holotype (Fig. 6A,B) is preserved as a foliage whorl flattened parallel to the bedding plane with the stem passing perpendicular into the matrix. Five radiating foliar lobes are attached by broad bases to an axis c. $10 \mathrm{~mm}$ in diameter to which a finely striated stem internode fragment is still attached; the lobes are all incomplete, to $>120 \mathrm{~mm}$ long and to $20 \mathrm{~mm}$ wide; widest at half their length and tapering distally. The foliar lobes are formed from three to six leaves closely conjoined for their whole length; each leaf marked by a broad indistinct midrib and by longitudinal striations. The paratype (Fig. 6C) shows portions of two foliar whorls, one with four lobes and the other with two lobes present but the whorl is incomplete. The foliar whorls are closely associated with finely striated stems, one with an internode length of 46 $\mathrm{mm}$ and with c. 20 longitudinal ribs and grooves in a width of c. $10 \mathrm{~mm}$. An adjacent stem is c. $0.7 \mathrm{~mm}$ wide with internodes c. $26 \mathrm{~mm}$ long.

Type material. HoLOTYPE AM F60570. PARATYPE AM F60569.

Type locality. Wave platform $600 \mathrm{~m}$ south of Turrimetta Head, late Early Triassic Newport Formation, Sydney Basin. GR 434 699, 1:100 000 Sydney Geological Series Sheet, $1983 ; 33^{\circ} 41^{\prime} 57^{\prime \prime S} 151^{\circ} 18^{\prime} 37^{\prime \prime E}$.

Etymology: jonesii-after Mr Robert Jones, long time manager of the palaeontology collections of the Australian Museum and collector of the type specimens.

Discussion. The genus Schizoneura, with opposite symmetrical pairs of foliar lobes that contract basally to form a sheath, differs from Paraschizoneura which has four or more foliar lobes, not necessarily symmetrical and that do not contract basally to form a basal sheath although this latter feature is rarely observed. Paraschizoneura jonesii is 


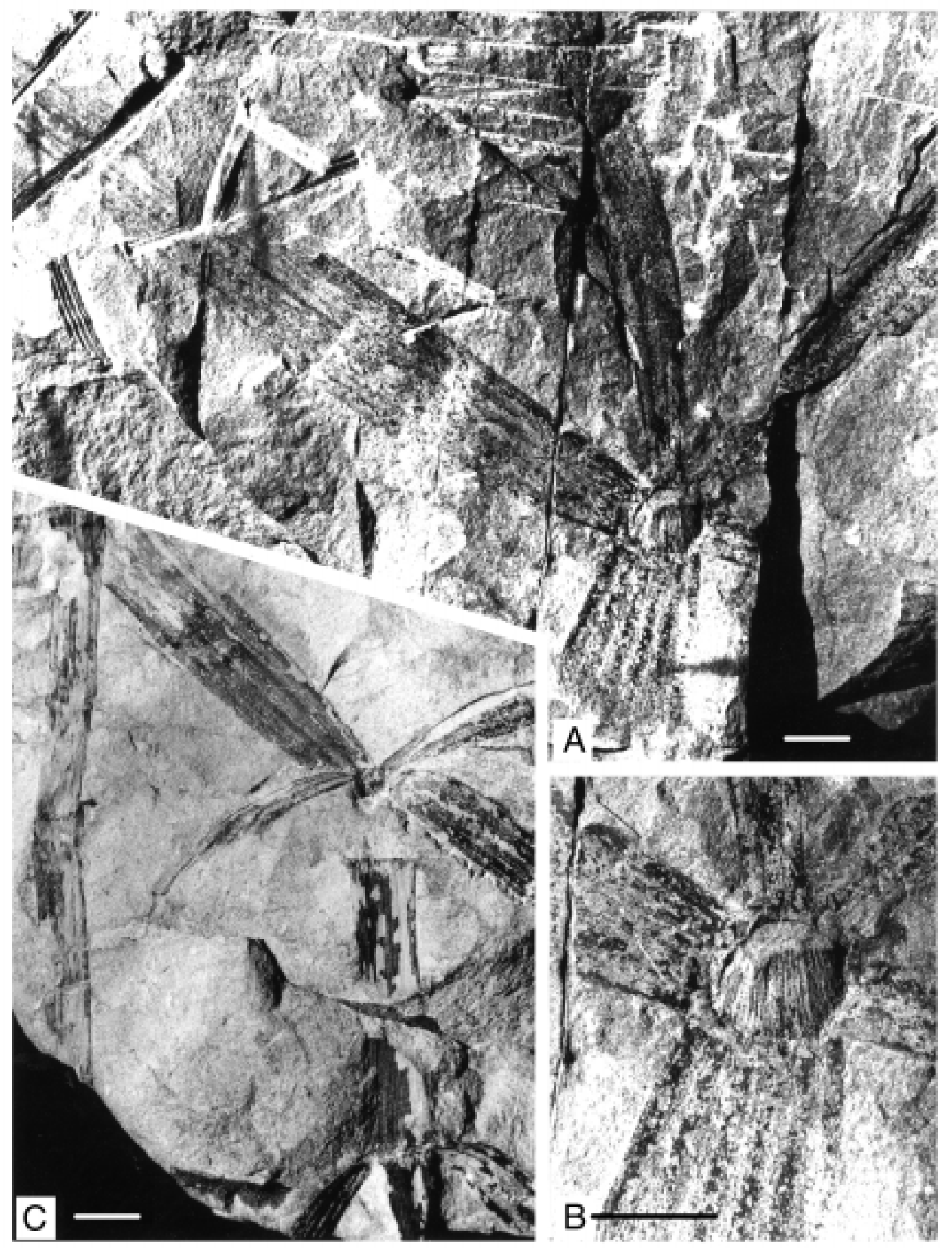

Figure 6. A-C; Paraschizoneura jonesii n.sp. from Turrimetta Head; A,B, holotype, AM F60570; C, paratype, AM F60569. Scale bars $1 \mathrm{~cm}$. 
closely comparable in gross morphology with Schizoneura africana Feistmantel from the Middle-Upper Permian Beaufort Group of the Karoo Basin, South Africa (Seward, 1908, text-fig. 2; Anderson \& Anderson, 1985, p. 103, fig. 1 and pl. 42, figs. 1-4) and with Paraschizoneura czekanovski (Rasskazova, 1961 in Boureau, 1964) from the Upper Permian Tunguska Basin of Siberia (Boureau, 1964, fig. 384 ). Due to the wide temporal and geographical separation of these two forms and also to avoid possible erroneous assumptions of close relationships, I believe these Australian Triassic specimens are best described as a new species of Paraschizoneura.

Leafless equisetalean stems have no diagnostic features to justify their classification as Schizoneura or Paraschizoneura. Triassic stems referred to Schizoneura sp. by Walkom (1915, pls. 4,5; 1924, pl. 26, figs. 1,2), Chapman \& Cookson (1926) and Hill et al. (1965, pl. T1, fig. 5) should be placed in Paracalamites Zalessky (Rigby, 1966) or rather be considered unidentifiable.

ACKNOWLEDGMENTS. I thank Mr Bob Jones of the Palaeontology Department of the Australian Museum for helpful and friendly co-operation over many years; Professor Artabe and Dr Zamuner and other members of the staff at the Palaeobotany Department of the Museo de La Plata, La Plata, Argentina, who provided facilities for examination of their collections and assisted in many other ways; Dr Heidi Anderson of the National Botanic Institute, Pretoria, South Africa for helpful discussions and encouragement; Mrs Adela Romanowski of N.B.I. and the photographic section of the Australian Museum for help in preparing the illustrations for this paper; Mr Malcolm Bocking for assistance with coordinates and references and to the two anonymous referees for valuable suggestions.

\section{References}

Anderson, J.M., \& H.M. Anderson, 1985. Palaeoflora of Southern Africa. Prodromus of South African megafloras, Devonian to Lower Cretaceous. Rotterdam: A.A. Balkema.

Anderson, J.M., H.M. Anderson, S. Archangelsky, M. Bamford, S. Chandra, M. Dettmann, R. Hill, S. McLoughlin \& O. Rösler, 1999. Patterns of Gondwana plant colonisation and diversification. Journal African Earth Sciences 28: 145-167.

Archangelsky, S., R. Herbst \& M.I.R. Bonetti, 1995. Revision y actualization de la obre paleobotanica de Kurtz en la Republica Argentina. Actas Academie Nacional de Ciencias 11: 127-184.

Artabe, A.E., 1985. Estudio sistematico de la taphoflora de los Menucos, Provincia de Rio Negro, Argentina. Part 1. Sphenophyta, Filicophyta, Pteridospermophyta. Ameghiniana 22: 3-22.

Artabe, A.E., \& A.B. Zamuner, 1991. Una nueva equisetal del Triasico de Cacheuta, Argentina, con estructura interna preservado. Ameghiniana 28: 287-294.

Beeston, J.W., 1991. Coal facies depositional models, Denison Trough Area, Bowen Basin. Queensland Geology 2: 1-34.

Boureau, E., 1964. Traité de Paléobotanique. Vol. 3, Sphenophyta, Noeggerathiophyta. Paris: Masson et Cie.

Cameron, R.G., N.S. Meakin, D.J. Pogson, G.P. Colquhoun, E.K. Yoo, G.A.M. Henderson, A.Y.E. Warren \& E.J. Morgan, 1999. Sydney-Gunnedah Basin. Explanatory Notes, Dubbo 1:250 000 Geological Sheet, pp. 281-312.
Chapman, F., \& I.C. Cookson, 1926. A revision of the "Sweet" Collection of Triassic plant remains from Leigh Creek, South Australia. Transactions of the Royal Society South Australia 50: 163-178.

de Cabrera, J.D., 1971. Estudio de algunos ejemplares de genero Neocalamites en la Triásico de la República Argentina. Acta Geologica Lilloana 11: 113-124.

Du Toit, A.L., 1927. The fossil flora of the Upper Karroo Beds. Annals of the South African Museum 22: 289-420.

Frenguelli, J., 1949. Addenda a la flora del Gondwana superior en la Argentina. 3. Neocalamites carrerei. Physis 20: 150-158.

Gould, R.E., 1968. Morphology of Equisetum laterale and Equisetum bryanii. Australian Journal of Botany 16: 153-176.

Halle, T.G., 1908. Zur Kenntnis der Mesozoischen Equisetales Schwedens. Kunglia Svenska Vetenskaps-Akademiens Handligar 3: 1-56.

Hauke, R.L., 1983. Horsetails (Equisetum) in North America. Bulletin American Fern Society 10: 39-42.

Hill, D., G. Playford \& J.T. Woods, 1965. Triassic Fossils of Queensland. Brisbane: Queensland Palaeontographical Society.

Holmes, W.B.K., 1982. The Middle Triassic flora from Benolong, near Dubbo, central-western New South Wales. Alcheringa 6: 1-33.

Holmes, W.B.K., 1995. The Late Permian megafossil flora from Cooyal, New South Wales, Australia. Birbal Sahni Centenary Volume, pp. 123-152.

Holmes, W.B.K., 2000. The Middle Triassic megafossil flora of the Basin Creek Formation, Nymboida Coal Measures, New South Wales, Australia. Part 1. Bryophyta and Sphenophyta. Proceedings Linnean Society New South Wales 122: 43-68.

Holmes, W.B.K., \& S.R. Ash, 1979. An early Triassic megafossil flora from the Lorne Basin, New South Wales. Proceedings Linnean Society New South Wales 103: 47-70.

Jones, O.A., \& N.J. de Jersey, 1947. The flora of the Ipswich Coal Measures-morphology and floral succession. Papers Department of Geology, University of Queensland, n.s. 3: 1-88.

Kurtz, F., 1921. Atlas de plantes fosiles de la Republica Argentina. Actas de la Academie Nacional de Ciencias, Cordoba 7: 129-153.

McLoughlin, S., 1992a. Late Permian plant megafossils from the Bowen Basin, Queensland, Australia. Palaeontographica B 222: 105-149.

McLoughlin, S., 1992b. Permian sphenophytes from the Collie and Perth Basins, Western Australia. Review of Palaeobotany and Palynology 75: 153-182.

McLoughlin, S., 1993. Plant fossil distribution in some Australian Permian non-marine sediments. Sedimentary Geology 85: 601-619.

McLoughlin, S., S. Lindstrom \& A.N. Drinnan, 1997. Gondwana floristic and sedimentological trends during the PermianTriassic transition: New evidence from the Amery Group, Northern Prince Charles Mountains, East Antarctica. Antarctic Science 9: 281-298.

Osborn, J.M., \& T.N. Taylor, 1989. Structurally preserved sphenophytes from the Triassic of Antarctica: Vegetative remains of Spaciinodum, gen. nov. American Journal of Botany 6: 1594-1601.

Playford, G., J.F. Rigby \& D.C. Archibald, 1982. A Middle Triassic flora from the Moolayember Formation, Bowen Basin, Queensland. Geological Survey of Queensland, Publication 380: $1-52$.

Rayner, R.J., 1992. Phyllotheca: The pastures of the Late Permian. Palaeogeography, Palaeoclimatology, Palaeoecology 92: 31-40.

Retallack, G.J., 1973. Stratigraphy, Palaeobotany and Environmental Analysis of an area north of Sydney, New South Wales. B.Sc. Thesis, University of New England, Armidale. 
(unpublished).

Retallack, G.J., 1977. Reconstructing Triassic vegetation of eastern Australasia: a new approach for the biostratigraphy of Gondwanaland. Alcheringa 1: 247-277 plus microfiche supplement G1-J17.

Retallack, G.J., 1980. Late Carboniferous to Middle Triassic floras from the Sydney Basin. New South Wales Geological Survey Bulletin 26: 384-430.

Retallack, G.J., 1995. Permian-Triassic life crisis on land. Science 267: 77-80.

Rigby, J.F., 1966. Some Gondwana articulates from New South Wales. Symposium Floristics and Stratigraphy of Gondwanaland. Birbal Sahni Institute, Lucknow, 48-54.

Seward, A.C., 1908. On a collection of plants from South Africa. Quarterly Journal of the Geological Society 64: 83-108.

Taylor, T.N., \& E.L. Taylor, 1993. The Biology and Evolution of Fossil Plants. New Jersey, Prentice Hall.

Townrow, J.A., 1955, On some species of Phyllotheca. Journal and Proceedings of the Royal Society of Tasmania 89: 39-63.

Walkom, A.B., 1915. Mesozoic Floras of Queensland. Pt 1. Flora of the Ipswich and Walloon Series. (a) Introduction. (b) Equisetales. Geological Survey of Queensland, Publication 252: $1-51$.

Walkom, A.B., 1924. Fossil plants from Bellevue near Esk. Memoir of the Queensland Museum 8: 77-92.

Walkom, A.B., 1925. Fossil plants from the Narrabeen Stage of the Hawkesbury Series. Proceedings of the Linnean Society of New South Wales 50: 214-224.

White, M.E., 1986. The Greening of Gondwana. Frenchs Forest: Reed Books.

Zalessky, M.D., 1932. Observations sur les végétaux nouveaux paléozoïques de Siberie. Société Géologique du Nord Annales 57: 111-134.

Zeiller, R., 1903. Flore Fossile des Gîtes de Charbon du Tonkin. Paris: Étude Gîtes Min. France.

Manuscript received 29 February 2000, revised 25 August 2000 and accepted 7 November 2000.

Associate Editor: G.D. Edgecombe. 